\title{
The Next Generation?: a Comparison between Thailand's 1973 Protests and Thailand's 2020 Protests
}

\author{
Pongsapak Waiwitlikhit \\ Shrewsbury International School \\ 1922 Charoen Krung Rd, Wat Phraya Krai \\ Bang Kho Laem, Bangkok 10120 \\ Thailand
}

\begin{abstract}
This paper will analyse and compare the different determining factors in the success of student-led political activism in Thailand - focusing on the similarities and the differences between the 1973 and the 2020 student movements. Additionally, the paper will provide a brief history into the formation of student activism in Thailand along with the preceding events before 1973 and 2020 to gain an understanding of why the student protests have been able to become such a formidable political force in Thailand. By comparing the economic situation, the symbolic situation, and the technological situation that has contributed to the success of the 1973 protest in changing the government, the paper will attempt to shed light on whether or not the 2020 protests will also result in major changes.
\end{abstract}

Keyword: Student activism, Military, Thailand, University Student, Collective identity, Democracy, Discourse Networks

\section{Introduction}

In a country renowned for its political instability, Thai students are arguably one of the most influential groups in Thai politics. Since the Siamese Revolution of 1932, Thailand has faced 19 coups and 20 constitutional changes. The country is stuck in a vicious cycle of coups and revolution, with its political institutions facing reforms from waves of democratisation and military takeovers. Out of these three waves of democratisation $(1932,1973,1992)$ (Tejapira, K., 2016), students were a pivotal social group in the successes of two of them; they acted as the key drivers of the democratic movements of 1932 and 1973 (in the former they led and organised the coup and in the latter they organised a nationwide protest against the government).

In the years since the 1973 democratisation movement, commonly known as the Popular Uprising, Thai students, however, have declined in their influence in politics. During the 1992 wave of democratisation, students were not leaders of the movement, instead serving as a branch of a wide group of protesters. However, after the 2014 coup which installed General Prayut Chan-ocha as the uncontested leader of Thailand, student political power is back on the rise. 2020 has so far seen the resurrection of an extensive nationwide, student-led protest movement against the military government, with its biggest protest yet numbering around 30,000 to 50,000 protesters (Pongsudhirak, T, 2020). Given the vast numbers of similarities of the current protests to the ones in 1973, it is difficult to not draw comparisons between the protests: both were student-led, popular protests calling for the dissolution of the military government at the time. This paper will analyse the current 2020 protests and compare them to the 1973 student protests. Using a historical perspective through comparisons of past successful democratic movements, this paper will attempt to analyse whether or not the current protests will lead to a major change of government as the 1973 protests did.

\section{The Siamese Revolution of 1932}

Students first shaped the political landscape of Thailand as early as 1932, when a group of high-ranking Paris educated students known as the 'promoters' conspired with the military in staging the Siamese Revolution, which led to the ending of absolutist monarchical rule.

During the periods preceding the 1932 Revolution, Thailand was in a phase of rapid change. Under the global pressure to modernise, the monarchs of the Chakri dynasty, specifically King Rama IV (1851-1868) and Rama V (1868-1910), consolidated their power by creating a larger, more complex bureaucracy to reflect the standard of Western countries. In achieving the goal of creating a modern bureaucracy, the government employed skilled commoners and thus a new class of commoner bureaucratic elite and middle class was formed - which meant that for the first time in Thai history, commoners had significant power in influencing political movements. (Mead, 2004) 
In order to administer the bureaucracy, the monarchs saw the importance of education in training specialized officials. In 1899, the "civil service training school", later renamed as Chulalongkorn University, was opened with the intention of training government officials. During the years 1899-1934, Chulalongkorn University was the only university in the country and only 68 students graduated from the school per year. The tiny enrollment in tandem with the fact that Chulalongkorn University was heavily regulated by royalists to ensure loyalty to the King meant that domestic university students had little to no impact in Thai politics (Kasetsiri, 1986).

However, foreign educated students had a different story. In building the bureaucracy, the government also recognised the importance of Western education in the modernisation of the country. This led to King Chulalongkorn sending commoner students on scholarships to be educated at foreign countries with the intention for them to return and run the bureaucracy. Exposed to western ideology, these students admired the flowery visions of the French and Russian Revolutions and followed the Western ideals of Democracy, Nationalism and Communism. These students, although small in numbers (only around were sent 400 abroad on government scholarship funds) (Wyatt, 1984), were highly influential in the development of the Thai political institutions spearheading the country's political discussions during the 1920s. As most foreign educated students came from families of elite status, they were given influential positions when they returned to Thailand. These included Pridi Banomyong and Plaek Phibunsongkhram, both foreign educated students who returned into powerful positions. After observing the economic and political advancements of France and other European countries, these students were dissatisfied with the backward nature of politics and economics in Thai society and blamed the absolute monarchy as the cause for Thailand's lack of growth. In 1927, a group of seven Siamese students met in Paris to secretly begin talks about creating a popular democracy, a socialist state and a constitutional monarchy. After returning to Thailand later that year, they gradually built up a group of civilian officials and started the plot for the Khana Ratsadon, a party led by Pridi Banomyong (civilian faction leader) and Plaek Phibunsongkhram (military faction leader), to overthrow the monarchy. (Stowe, 1991)

Nevertheless, what truly enabled the success of the Revolution was the public dissatisfaction with the monarch. During the 1920s, public political opinion was primarily expressed by the Chinese middle class and the bureaucratic middle class since the peasants were preoccupied with worries about their basic subsistence needs. Because of the increased exposure to Western ideology, the frivolous spending of the Thai Monarchy, cases of corruption and the neglect of the middle class, there was a massive increase in civilian public disillusionment with the absolute monarchy. Furthermore, the monarchy also angered army officials. Inspired by the national paramilitary corps in European countries at the time, in 1911 King Vajiravudh (Rama VI) created the Wild Tiger Corps - his very own personal paramilitary group; this group consisted of up to 4,000 soldiers. Eventually, the political power of the group rivaled that of the commoner military (as the King appointed many members to powerful positions of the bureaucracy), angering many military officials at the time: as seen through the 1912 attempted coup by several military officials. Further instances of the monarchy angering the public can be seen by how the monarchy failed to maintain the government's fiscal health. Many of the commoner bureaucratic middle class viewed King Rama VI's spending as extremely unnecessary: he spent up to $8 \%$ of the state's budget on his coronation in 1910. The lavish spending by the monarchs and the court meant that by 1925, during Rama VII's rule, Thailand was in a massive government deficit - breeding dissatisfaction with the monarchy among the general public.

The event that truly marked the turning point in public dissatisfaction with the monarchy was the Great Depression of 1929. Despite the monarchy's budgetary mismanagement in the previous years, much of the middle class was content with life. This was to change with the arrival of the Great Depression. Rice, the dominant export at the time, dropped to $1 / 3$ of its value during 1932, which meant that many peasants were unable to pay their taxes. The lowered tax revenue led to a budget crisis that forced the government to cut its 1932 fiscal year spending. This lowered spending mainly affected the commoner bureaucrat officials, who were faced with freezes on promotions, harsh salary cuts, and a massive tax on salary, which was not levied on princes and the Chinese middle class. Because of the crisis, the lowered wages caused mass outrage among the middle class bureaucrats. Therefore, public opinion toward the government and the King plummeted (Wyatt, 1984)

Despite the outrage in the bureaucratic middle class, the "promoters" still had close to no support. There was not a unifying body at the time among the commoners, as many feared prosecution if they overtly protested, which meant that the promoters, a group led by freshly graduated civilian university students Pridi Banomyong and Plaek Phibunsongkhram (both graduated in 1927), along with several military officers, had to pretend that they had the majority support from the people. On the dawn of 24 June 1932, they set out to carry out a military coup while the King was on vacation in hopes that the military units and the government officials wouldn't retaliate. This 'Revolution' which was actually more reminiscent of a coup, led to the overthrow of absolute monarchical rule and the creation of a constitutional Thailand. (Wyatt, 1984) 


\section{A Brief History of Thai Student Activism}

During the period after the Siamese Revolution, from 1932 to 1967, students were often either apolitical or manipulated by political powers. (Morell \& Chai-anan, 1981, p137-139). Pridi's ambitious efforts to create a democratic country failed. In 1933, a coup was launched against the constitutional government by the military faction of Khana Ratsadon, which included many members who were nationalists and staunch anti-communists. Viewing democracy as an unobtainable cause; the military effectively turned Thailand into a military dictatorship by 1938, with only a brief period of civilian rule post Second World War (Wyatt, 1984). Under the Phibunsongkhram government (1938-1944 and 1948-1957), student influence was negligible - with the most remarkable action being the occupation of the Grand Palace by Thammasat University students to show support for Pridi and the civilian leaders who attempted to restore civilian government during the 1949 coup attempt that ended in failure. And although during the period after the 1957 election, student protesters, along with many workers and professionals, rallied to accuse the Phibunsongkhram government of rigging the election, these protests were manipulated by the military regime of Sarit Thanarat. He secretly assisted the students in their protest against the Phibunsongkhram government with the ulterior motive of using them to legitimize his coup by portraying how he had support from different societal classes. Through the use of these student protests Thanarat was able to gain political control after the resignation of Phibunsongkhram. With the emergence of Sarit Thanarat as an unchallenged military dictator (1957 - 1963), student activism completely disappeared; the severe restrictions on political rights - especially leftist views - meant that activism was co-opted and repressed, with many intellectuals and activist leaders being prosecuted (Darling, 1974). However, ironically it was under Sarit Thanarat's regime that began the revival of university students as a force in politics.

The authoritarian regimes of Sarit Thanarat (1957 - 1963) and his successor Thanom Kittichakhon (1963 - 1973) marked one of the most rapid developmental periods - unprecedented in modern Thai history; GDP per capita increased at a rate of $8 \%$ annually, causing massive social transformation. The regime understood the importance of universities in facilitating economic development. Not only were highly skilled workers and technocrats sought out by the government to manage an increasingly complex bureaucracy, an increasingly large number of businesses in the private sector sought to increase their competitive edge by employing highly educated and specialized workers. Under The National Economic Development Plan of 1961, the government established many universities and vocational training institutes across Thailand. With the emergence of these universities, higher education expanded to all socio-economic classes - providing higher social mobility. As a result, student enrollment in universities skyrocketed: enrollment increased from 15,000 to 100,000 students between the years 1961 to 1970 (Prajak, 2005, p 43\&94-99). This meant that students were able to gain political leverage due to a larger pool of students for protests and activism.

However, more significant than the increase in enrollment, was the elite status that students possessed in society because higher education was still not normalized into civil society. In this day and age, since access to education has greatly expanded, university students are held in less reverence. However, during the 1940s and 1950s only the wealthiest were able to afford higher education, and therefore most of the older generation viewed university students as elite: more informed and better educated than the general population. The government and the civilians of Thailand attributed students with the view that they will become the next generation of "leaders bringing progress and prosperity to the country"(Kongkirati, 2012 ), which meant that the opinions of university students were taken very seriously among the general population. As Thailand developed, higher education was more widely accessible to the common population, however, the view that university students were elite stayed. This view heavily influenced the actions of university students during the authoritarian regimes during the 1960s and 70 s, as they developed a sense that they had a social responsibility to the people: they were expected to take care of the less privileged due to their elite status. Under development programs such as the Peace Corps, during the school breaks students would volunteer to go to the countryside and help develop rural villages. At these villages students were faced with the harsh, poverty ridden living conditions of rural Thailand and were disappointed by the lack of progress governmental programs had made in developing the country for its poor. (Bartak, 1993) Eventually, due to their expectations of being the country's next generation of leaders and their increasing disillusionment with the lack of progress, Thai students formed a collective identity of the 'naksueksa' (student) in which they attempted to solve the social problems to protect the poor, exploited citizens of Thailand - openly criticizing and challenging the government when the government's actions were deemed against the interests of the people.

Nevertheless, despite having a broad power base and a collective identity to rally around, progressing to a more openly critical stance towards the government took several years. Sarit Thanarat was extremely successful at repressing any student activism during his regime. After his accession to power, he immediately banned radical publications and threw writers, intellectuals and student leaders into jail. Additionally, Thanarat also heavily regulated campus activity; he restricted many groups and banned political organisations to reduce the likelihood of student protests. 
However, after Sarit Thanarat's death the formation of a student discourse network, economic downturn, and public support led to the reemergence of the student activist - who eventually became the hallmark of demonstrations against the Thai military regime. The Thai student movement culminated in the Popular Uprising of October 1973 ultimately successful in causing a major regime change that benefited the common people.

\section{The student mobilization in 1973 and factors for student success}

The emergence of student activism in the late 1960s created Thailand's first solely student-led movements, dissimilar to previous movements as they were significantly bigger and were non-partisan (unlike the pre-1960s protests organised in support of Sarit Thanarat and Pridi Banomyong). The first signs of rekindled activism against the military government occurred in 1968 - when students from Thammasat University organised a massive demonstration outside the Thai Parliament to protest against martial law and to demand the creation of a democratic constitution. This protest led to the 1968 Constitution, which despite seeming democratic on the surface, actually acted as a form of democratic legitimating of Thanom Kittikachorn's rule. In the following year, students held even larger demonstrations against the proposal to raise the price of government funded bus fares by $30 \%$ - in which they successfully caused the government to withdraw its proposed pricing. Student protesters in Thai politics grew increasingly significant near the end of Kittikachorn's rule. After the 1971 coup by Kittikachorn to dissolve his own parliament and reinstitute martial law, university students were again the vanguard of the movement against the 'tyranny' of the military regime; during the 1973 October demonstrations, students organised marches that numbered up to 500,000 people outside the Victory Monument, which led to Kittikachorn's resignation. To understand how the students were so successful in changing the political landscape, one would have to look at the background factors that caused the student movement to become such a big player on the political landscape by 1973.

One of the factors that enabled the students to mobilize was the formation of a student discourse network. Under the rule of Kittikachorn, political repression loosened; the military rulers were more tolerant of intellectual movements in student communities. This resulted in the formation of independent political discussion groups such as the "Sapha Na Dome" (สภาหน้าโดม), the "Sethatham", and the "Fuen Foo Sotus Mai", which embraced an eclectic mix of radical and moderate ideologies including Marxism, Democracy, Nationalism and Monarchism. These independent groups produced journals and publications advocating for their ideologies and condemning the Thai government (Kongkirati, 2012), accusing the military regime of imperialism and investigating government corruption. Known as "One Baht Journals", publications and newspapers produced by such groups were easily accessible and thus quickly spread throughout Thai universities, being sold in front of many university gates. With more and more students being exposed to the progressive media promoting alternative ideas critical of the government, the students gradually became the forefront of the Thai intellectual movement. And despite their clashing ideologies, these publications and journals formed a large base of individuals with a shared common political goal: to oppose the military regime and to call for democracy. This group of students was bureaucratised through the National Student Center of Thailand (NSTC), an interuniversity group which connected student union groups all over the country. Created in 1968 to organize non-political activities between student societies, this union amassed up to 100,000 students by spring of 1973. This centralized organisation of the group allowed for successful coordinated mobilization of student protests and negotiation with the government. (Darling F. C. , 1974 | Prizzia R. , 1985)

Similar to the 1932 Revolution, the success of the students depended on a failing economy. Arguably more important than the formation of discourse networks to the increasing political strength of student activists was the economic slump that Thailand was facing in the late 1960s and the early 70s. Throughout the Sarit Thanarat regime, Thailand was in a period of economic boom: GNP increased by a rate of $8 \%$ every year, lifting millions of people out of poverty and raising living standards for all. For the university students, this meant that after graduation, prospects of a well-paying and stable career in a private company or in the bureaucracy were high. However, by the late 1960s, this economic boom was starting to come to an end. With America pulling out of the Vietnam War in the early 1970s, financial aid provided by the Japanese and the US dropped sharply, and many war-related businesses experienced a drop in sales. Thailand's GDP growth fell from averaging around $8 \%$ during the years 1963-1969 to a mere 4.5\% in 1971, the lowest GDP growth that Thailand had experienced in many decades (World Bank). What this meant for the students of Thailand was that secure employment was no longer a guarantee once they graduated. The expansion of employment in the public sector, where the majority of students aspired to work, dropped from $10 \%$ a year between 1957 and 1967, to only $2 \%$ from 1968 onwards, while private employment, similarly, also reduced (Prajak 2005, 93). This, in tandem with economic problems such as inflation and housing shortages, meant that students were increasingly dissatisfied with the government and grew even more critical of their regime, drawing in a bigger base for political mobilization. 
Finally, a factor that also helped contribute to the successful student movement was the widespread support they had from the general public. The economic crisis of the 1970s heavily affected the general population of Thailand. This crisis was worsened by a severe drought in 1972, leading to a sharp decline in rice exports. Many citizens blamed the government for its inability to curb inflation (with inflation rates rising to $15.51 \%$ in year 1973) and provide stable rice supplies for the country, meaning that, despite the fact that the middle class were unconcerned about specific student objectives such as the demand for democracy, they supported their protest against the government. (Wright, 1991, p212-216) Furthermore, the student protesters were able to gain additional support from the citizens through their nationalistic campaigns and support of the monarchy. Not only did they organise boycotts against Japanese goods in 1971, students displayed their loyalty to the monarchs of Thailand by carrying posters of the King and Queen during protests and singing the King's anthem; Through their nationalist campaign they were seen as patriotic fighters and so they gained support from every social group of the country: the conservatives, the monarchists, the workers, and the liberals. (Prizzia, 1985)

These factors combined meant that the student movement of 1973 was not only able to garner a massive base of protesters able to mobilize, but also had general support from the population. Triggered by the arrest of students campaigning for democracy, during October 13-14, university students organised a 500,000 strong march joined by many members of the outraged public outside the Democracy Monument; a historical event which marked the largest political demonstration ever seen in Thailand. Eventually, after failed attempts by the government to defuse the situation diplomatically and increasing violence between the protesters and the military, King Rama IX announced that the military government of Thanom Kittikachorn had resigned. Because of how the King handled the event, the King was seen as the mediator between the military and the students, with many in the public now attributing his actions as promoting democracy in the country. This protest, known as the "Thai Popular Uprising," resulted in a shift towards democracy. (Prizzia, 1985)

\section{Decline in student protest power 1976 - 2014}

For a few years (1973-1976) after the Thai popular uprising, student activists remained relevant to the political landscape. However, by 1977 student protesters were once again insignificant in Thai politics. In the years after the Popular Uprising, Thailand was marked by instability and chaos. The end of the Vietnam War and the abolition of the Burmese monarchy meant an increasing fear of a communist revolution in Thailand. As students gradually gravitated towards the left, far right groups began violent campaigns against communism and leftist political demonstrations. The growing unrest convinced political leaders to revert their political system back to the despotic military rule of before through the support of the growing far right movement; in August of 1976, the government invited former military leader Thanom Kittikachorn and Praphas Charusathien back to Thailand. This event sparked massive outrage and led to a student demonstration in October 1976 at Thammasat University. With political polarization at an all time high, the right wing mob along with government sponsored paramilitary groups gathered at the gates surrounding the university campus. Accused of breaking Lese-Majeste laws and conspiring in a communist takeover, the student protesters were violently repressed by the right-wing paramilitary groups and the Thai police. This tragedy, which Thais refer to as the "6th of October", led to over a hundred deaths. This marked the end of the student-led political movement and the return of the military rule - a coup was orchestrated to appoint Prime Minister Thanin Kraivichien in the immediate aftermath of the event. (Handley, 2006)

Following the 1976 Coup, a countercoup was launched in 1977 to depose Kraivichien, who was widely unpopular among the public. This coup appointed Kriengsak Chamanand as the Prime Minister of Thailand. Despite his seemingly undemocratic ascension, Kriengsak's government was viewed by the general public as steering Thailand towards democratic values because he promised to address absolute poverty in Thailand and to restore democracy by 1979. This meant that student protesters lost their collective goal and role for mobilization. Furthermore, university students had lost their 'elite' and 'noble' status in society. The consolidation of higher education as a mass commodity meant that students were no longer seen as 'special' and different from the rest of the population. These factors contributed to the reduced political activism students performed in Thailand. Although students still participated in activism during periods of crisis in 1977 - 2014, rather than leading the protests, they instead served more as branches of broad political movements (Prajak, 2005). This meant that during the third wave of democratisation in 1992, students were not major leaders of the movement. It was not until the 2014 Coup that students once again emerged as a large political force.

\section{Re-Emergence of Student Activism post 2014}

One of the main factors behind the reemergence of student activism post 2014 was the reestablishment of a collective identity and goal.

The 22nd May 2014 Coup appointed the National Council for Peace and Order (NCPO) as the unchecked ruler of the country. This coup, led by General Prayuth Chan-ocha, was met with both praise and scrutiny. Many members 
of the PDRC ("yellow shirts") supported the coup, viewing it as ending corruption and providing stability to the country.

However, a widespread group of people viewed the coup as undemocratic: accusing the NCPO of being an illegitimate regime. The very day after the coup, students from Thammasat and Mahasarakham universities organised protests in support of a widespread anti-coup movement ("ทหาร ไล่เก็บ", 2014 | "Activists rally against", 2020). In the following years, 2016-2020, small-scale student-organised protests were prevalent across Thailand. Student activists, who were earlier dis-unified by the identity politics of the 'yellow' and 'red' shirt movements, once again had a collective ideological goal they could unite behind. They began to develop unifying symbols of resistance as a form of protest against the military government - adopting the Hunger Games Salute, sandwich eating, and the book 1984. Viewing themselves as the voice of democracy and the resistors of dictatorship, student demonstrators once again assumed a well-defined role in society: to return democracy to the country.

The 2019 election increased societal discontent with the military. This election was commonly regarded by observers as being 'partly free and unfair' - with studies viewing the election as a ritual to 'transform the military junta into an elected government.' (Sawasdee, 2019) Further discontent was caused by allegations of corruption in the military regime, with an example being the junta's involvement in the 1MDB Malaysian fund scandal. However, the catalyst of a larger scale student protest was the disbanding of the Future Forward Party on 23 February 2020. Many students identified with the progressive nature of the party and were outraged when the Constitutional Court disbanded the party on the egregious claim that the party had violated election laws by receiving a 191.2 million baht donation from its leader Thanathorn Juangroongruangkit (Gunia, 2020 | "Future Forward: Thai", 2020). Brewing discontent with the undemocratic military regime among the student population culminated in the first student-organised protests in more than 40 years in February 2020. (“แฟลชม็อบนักเรียน", 2020)

\section{The student mobilization in 2020 and its comparison to 1973}

In comparison to the 1973 student mobilization, the 2020 activists also formed a network of discourse; this network can be highly accredited to the advent of social media in spreading news and ideas. Immediately after the 2014 coup, online spheres of anti-coup and anti-military thought formed on Twitter, Facebook and Line. These spheres were hard for the government to regulate and enabled students to learn about the faults of the military government, human rights issues and injustices within the current system. To give a sense of the widespread scale of these online spheres, the hashtag \#ถ้าการเมืองดี (If Politics was Good) had over 120,000 tweets referencing it in a period of a single day (Satrusayang, 2020). Additionally, there was growing mass disillusionment towards the government after footage captured the forced disappearance of pro-democracy and anti-junta activist Wanchalerm Satsaksit. With the internet believing that the government was behind his abduction, the hashtag \#SaveWanchalerm trended on Twitter for weeks and led to a demonstration at a skywalk in Bangkok (“\#SaveWanchalerm Bangkok", 2020). Thus, these online discourse spheres brewed student discontent and outrage towards the government.(Kri-aksorn, 2020) Furthermore, the social media spheres allowed groups to organise and coordinate student activity. Through using social media, the 'Free Youth' organisation was able to broadcast their 3 core demands to the wider public during smaller demonstrations (including 2500 people during July). Persuasive speakers at the United Front for Thammasat and Demonstration, such as Panusaya Sithijirawattanakul and Anon Nampa, organised public protests to spread ideas like the 10-point manifesto for reform of the monarchy. (““เยาวชนปลดแอก” เปิด”, 2020 | Wangkiat, P., \& Mahtani, S., 2020 |“[Full statement] The", 2020) This meant that, similar to the 1973 protest, the 2020 protests also had a large discourse network which allowed students to coordinate their movement.

In spite of this, the major weakness of the 2020 protests is that the movement lacks centralisation. Unlike the NSTC, which organised all student activity during the 1973 movement, the current protests are coordinated by smaller and decentralized online spheres. The heterogeneous and leaderless organisation of the 2020 protests has its upsides, as it hinders state attempts to weaken the movement via arrests of key protest leaders ("Jha P., 2020). However, it also means that the current movement lacks unified goals and a centralized body for negotiating with the government. Scholars such as Yingcheep Atchanot and Yutthaporn Issarachai argue that without a more centralised and united organisation of the protest movement, it is unlikely that the protest will lead to great change (Vipoosanapat, 2020 | "Loss of protest", 2020).

Another similarity between the 1973 movement and the 2020 protests is how they occurred at the same time as an economic crisis, a similarity which is also shared with the Siamese Revolution of 1932. The Covid-19 crisis had devastating effects on the Thai economy. Under national lockdown regulations, the tourism sector's annual revenue, which comprises $18 \%$ of the Thai economy, is expected to shrink by $75 \%$ in 2020 ("Tourism revenue", 2020). Additionally with Thai unemployment levels at averaging at nearly $10 \%$ in August and the economy predicted to shrink by $8 \%$ in $2020,70 \%$ of the workforce has seen a decline in wages from March to August. (Jassen P., 2020) Due to the failing economy, there is likely to be increased political polarization among the 
population, with many blaming the current government for their financial hardship and supporting the student's protests.

According to an International Crisis Group's interview of an unnamed Thai Academic, "Politics is going to change with this level of hardship. You can't expect things to stay the same". ("Covid-19 and a Possible", 2020) There are long lasting implications of the public hardships that may come in the coming months. Discontent with the government may grow as the economy goes deeper into recession. Protesters may be joined by students who are currently struggling to find employment, and, with the average income of the nation falling every day, many members of the public will be more willing to support the anti-government protests.

However, one of the key differences between the 1973 protests and the 2020 protests is the mixed support that students have among the general public. As mentioned previously, the expansion of higher education in Thailand meant that students have lost their elite status in society. Due to government policies, Thailand's total number of university students increased dramatically from 100,000 in 1972 , to 677,480 in $1985,800,441$ in 1998 , and $1,979,782$ in 2008. By 2020, it became increasingly common to enroll in higher education. (Prizzia R. , 2020) This has normalized the place of students in civil society, and thus rather than viewing student protesters as the righteous protectors of the country's future, the general population now increasingly sees them as just another social group.

More importantly is the fact that when compared to the 1973 movement and the 1932 Revolution the country has had a more polarized response to the 2020 student protesters. In the 1973 protests the majority of the public was discontented with the government. This was reminiscent of the 1932 Revolution, in which the majority of the public bureaucrats were discontented with the absolute monarchy. However, the 2020 protests are different from the 1973 and 1932 Revolutions in that there is a large base of opposition against student demonstrators among the middle class (Wilson, J., \& Satrusayang, C., 2020). A poll conducted during September 2020 found approximately equal support for the majority government parties and the opposition parties of the parliament (with the majority and opposition party holding $24.98 \%$ and $32.09 \%$ support respectively) ("Slight majority", 2020). Although the majority of respondents had no opinion of which political party to support, there was still a relatively large base of support for the military government from monarchists and conservatives. Up to $28.64 \%$ of respondents in another survey thought that the students are sowing division and creating disorder in a time of crisis, with many arguing that the students are all part of a political game by hungry politicians ("Majority agree", 2020). They view the military regime as upholding the country's key values and bringing stability to a country that faced many years of political turmoil. Furthermore, the majority of the population views the government's handling of the Covid-19 crisis as a major success. In a poll conducted during May 2020, most of the respondents were satisfied with the government's quarantine measures. In October 2020, up to 55\% of respondents in a poll were against the opening up of the country, despite the clear crisis the tourism sector faced ("Majority against", 2020). This meant that in response to the students' protests, many members of the population vehemently disapprove of their action. Staunch monarchists and Conservatives have formed groups such as the "Rubbish Collector Organisation" to mobilize counter-protests to show their disapproval of the students - amassing up to 300,000 members on their Facebook page (contesting the membership numbers of student demonstrator groups). ("Thailand's protests and", 2020 "องค์กรเก็บขยะ", 2020)

Despite this, it seems as though a slight majority of the Thai population supports the students in their movement. In a poll conducted during August 19-21, 61.32\% of the respondents agreed with the students' demand for a constitutional amendment - with many viewing the current government system as being undemocratic - and $53.88 \%$ of respondents demanded that the parliament be dissolved. However, despite the agreement that a constitutional change is needed, it currently seems as though the students' demands are deemed too radical for the general population, with only $26.48 \%$ of respondents believing that the students' changes will be for the betterment of the country. It is difficult to compare popular support for student protests in 1973 and 2020 as for the former we lack conclusive polling data to make definitive statements about the national sentiment of the protests. However, given that the 1973 students' movement appealed to every social group in that era while the 2020 movement fails to appeal to conservatives and monarchists, it seems reasonable to say that support for the 2020 protests is more polarized when compared to 1973. ("Majority agree", 2020)

Another discontinuity between the current student movement and the 1973 movement is their stance toward the monarchy. While the 1973 protests upheld the monarchy, the current student movement of 2020 has advocated limitations on the power of the monarchy. The 2020 movement is similar to the 1932 Revolution in this aspect, as both demanded the reformation of the monarchical system. They argue that it uses too much of the national budget (currently King Rama X holds 43 billion dollars in assets) and that the King interferes with political affairs through coups. The student-organised protests during August 2020 contained a 10-page manifesto which asserted that the King "is not above politics"("[Full statement] The", 2020), an allusion comparable to the Khana Ratsadon Manifesto which called for the King to be put "under the law of the constitution"(Banomyong, P., Baker, C., \& Phongpaichit, P. , 2000). Furthermore, the current protests demand the repeal of pro-monarchy laws such as the 
Lese Majeste, the reduction of national assets allocated to the crown, and for the King to not be involved in politics. For the first time in Thai history, there is a protest which is openly critical of the King. Many demonstrators of the October 15-17 protests can be heard chanting "ไอ้เหี้ยโอ" which translated to $\mathrm{F}^{* * *}$ You Oh (Oh is a nickname of the King) - an act that a few months earlier would have landed a student in jail due to Lese Majeste laws. (ประยุทธ์ จันทร์โอชา, 2020)

Given that the support of the monarchy was a major determinant in forming popular support for the student movement during the 1973 protest, many argue that these anti-monarchy actions may be detrimental to the success of the current movement. Many members of the public were quick to attack the students' demand for monarchy reform (ตั้งธรรมนิยม K. , 2020) and government officials even attempted to censor the 10-point manifesto ("Thai PM says", 2020). Currently, King Rama X has taken an ambiguous stance towards the protesters. In the past it seemed as though he was unwilling cooperate with the student movement: he stated after the 16 October demonstrations that "Now it is understood that the country needs people who love the country and love the monarchy" and he praised a counter-protester who raised a picture of King Rama X during an organised student protest (“ในหลงตรัส”, 2020| Beech H. , 2020). However, on the 2nd of November, the King has also shown signs of willingness to negotiate with the students - stating that Thailand is the "Land of Compromise" and that he "loves [all Thais] the same" ("King declares", 2020).

Despite this, while there is still certainly extensive support for the monarchy in the population, especially among the conservatives and right wing, in recent years there has been greater discontent with the monarchical system. With the passing of the much revered King Rama IX, the transition to the slightly more controversial Rama X has created increased discontent with the monarchical system. Although public sentiment regarding the Thai monarchy is difficult to gauge as the Lese-Majeste laws prohibit the conduct of opinion polls about the King, there is qualitative evidence that public reverence of the monarchy is deteriorating. Many online spheres have emerged which are openly critical of the Thai monarchy. The most popular of these is a Facebook group known as the Royalist Marketplace (รอยัลลิสต์มาร์เก็ตเพลส-ตลาดหลวง, 2020), which has attracted up to 1.6 million members. The current King faces criticism about his lifestyle, his apparent indifference to Thailand's Covid-19 situation while living in Bavaria, and scandals about his affairs. Currently the hash tag \#republicofthailand is trending and has gained over 700,000 retweets - the first evidence of mass sentiment favoring the dissolution of the monarchy ("Getting radical?", 2020).

\section{The Future of the Protests}

In assessment of the direction that the current Thai protests are heading, the majority of scholars have taken a pessimistic view towards the future of the student movement. Some have noted the divided support of the 2020 student protest, with political scientist Dr. Kanokrat Lertchoosakul questioning whether the students will be able to effectively overcome the "supportive political environment and a much more unified elite [of the military], along with a right-wing middle class movement".(Wilson, J., \& Satrusayang, C., 2020) Other scholars such as Yutthaporn Issarachai and Athith Keating (a pseudonym for an undisclosed human rights activist) have long been wondering whether or not the student movement will be able to coordinate more targeted movements that will be able to negotiate change with the government. ("Loss of protest", 2020 | "Opinion: Student", 2020). Another major fear is the repeat of violent repression similar to the 1976 Thammasat Massacre. Many political scientists, including Dr. Chaiyan Chaiyaporn, Dr. Piti Srisangnam (Sattaburuth A., 2020) and Phichai Ratnatilaka Na Bhuket ("Loss of protest", 2020), fear that as the disruptive nature of the protests intensifies, the government will respond more violently - with Mr. Na Bhuket fearing that the state of emergency issued in mid-October is a "signal that the government may be ready to use force".

While the chance of achieving the students' idealistic goal of complete House dissolution may be bleak, scholars are hoping for a peaceful resolution of the 2020 protests; Dr. Chaiyaporn, Dr. Srisangnam (Sattaburuth A. , 2020) and Mr. Somkiat Tangkitvanich ("Somkiat warns", 2020) are urging the government to step up and negotiate to settle the differences they have with the protesters. With the current trajectory of the Thai student protests, an undisclosed member of the Pheu Thai Party states that although "the chances of a House dissolution or the resignation of the Prime Minister is nearly zero" he urges the government to make "constitutional amendments" to achieve the best possible outcome in this situation. ("Loss of protest", 2020)

\section{Conclusion}

Overall, in predicting whether or not the 2020 movement will cause a major restructuring of power as in the 1973 student movement, it can be concluded that while the 2020 movement may result in an amendment to the constitution, it is unlikely that the 2020 movement will result in the dissolution of the government. Similar to 1973, the movement is fueled by economic crisis, support from the population and a discourse network due to social media innovation. 
However, with support from the population being divided and discourse networks being decentralized, the 2020 protests will be unlikely to gain as much momentum and negotiating power as the 1973 movement did.

Although currently it is speculation whether or not the 2020 movement will cause major change in political structures, it seems as though the 2020 student demonstration will have a harder time in achieving its goal of a Thai Democracy.

\section{References}

Activists rally against coup in Bangkok. (2014, May 23). Prachatai. https://prachatai.com/english/node/3991

Banomyong, P., Baker, C., \& Phongpaichit, P. (2000). Pridi by Pridi: Selected Writing on Life, Politics, and Economy. Silkworm Books.

Bartak, E. (1995). The Student Movement in Thailand. Monash Asia Institute.

Beech, H. (2020, October 16). Thailand Steps Up Response as Antigovernment Protests Escalate. The New York Times. https://www.nytimes.com/2020/10/16/world/asia/thailand-protests-bangkok.html

COVID-19 and a Possible Political Reckoning in Thailand. (2020, August 4). International Crisis Group. https://www.crisisgroup.org/asia/south-east-asia/thailand/309-covid-19-and-possible-political-reckoningthailand

Darling, F. C. (1974). Student Protest and Political Change in Thailand. Pacific Affairs, 47(1), 5-19. https://doi.org/10.2307/2755892

[Full statement] The demonstration at Thammasat proposes monarchy reform. (2020, August 11). Https://Prachatai.Com. https://prachatai.com/english/node/8709

Future Forward: Thai pro-democracy party dissolved over loan. (2020, February 21). BBC. https://www.bbc.com/news/world-asia-51585347

Getting Radical? Thai netizens call for the "Republic of Thailand." (2020, September 25). Thisrupt. https://thisrupt.co/current-affairs/thai-call-for-republic-of-thailand/

Gunia, A. (2020, January 20). Thailand's Future Forward Party Has the Support of Young Thais. A Court Could Disband It Entirely. Time. https://time.com/5756668/thailand-future-forward-party/

Handley, P. M. (2006). The King Never Smiles: A Biography of Thailand's Bhumibol Adulyadej (First Edition). Yale University Press. https://doi.org/10.2307/40860861

Janssen, P. (2020, August 14). Thailand's Covid success turns economic failure. Asia Times. https://asiatimes.com/2020/08/thailands-covid-success-turns-economic-failure/

Jha, P. (2020, October 21). Thailand protest: Why young activists are embracing Hong Kong's tactics. BBC. https://www.bbc.com/news/world-asia-54626271

Kasetsiri, C. (1986). Pridi Banomyong and Thammasat University (1st ed.). Thammasat University Press.

King declares "love" for all, calls Thailand "land of compromise." (2020, November 2). Bangkok Post. https://www.bangkokpost.com/thailand/politics/2012131/king-declares-love-for-all-calls-thailand-land-ofcompromise

Kongkirati, P. (2005). และแล้วความเคลื่อน ไหวก็ปรากฏ. SameSkyBooks.

Kongkirati, P. (2012). Thailand: The Cultural Politics of Student Resistance. In M. L. W. Weiss (Ed.), Student Activism in Asia: Between Protest and Powerlessness (pp. 229-258). Univ Of Minnesota Press. https://doi.org/10.1080/00472336.2013.868999

Kri-aksorn, T. (2020, August 19). All you need to know about Thai protests. Https://Prachatai.Com. https://prachatai.com/english/node/8734

Loss of protest leaders "critical." (2020, October 16). Bangkok Post. https://www.bangkokpost.com/thailand/politics/2002815/loss-of-protest-leaders-critical

Majority against opening country to foreigners: Poll. (2020, September 12). Bangkok Post. https://www.bangkokpost.com/thailand/general/1950072/majority-against-opening-country-to-foreigners-poll

Majority agree with Free People group's demands: Poll. (2020, August 23). Bangkok Post. https://www.bangkokpost.com/thailand/politics/1973067

Mead, K. K. (2004). The Rise and Decline of Thai Absolutism (Routledge Studies in the Modern History of Asia) (1st ed.). Routledge. https://doi.org/10.4324/9780203644300

Morell, D., \& Samudavanija, C. (1988). Political Conflict in Thailand: Reform, Reaction, Revolution. Oelgeschlager Gunn \& Hain. https://doi.org/10.2307/2054853

Opinion: Student Protest Leaders Lack A Coherent Strategy. (2020, August 13). Khaosod English. https://www.khaosodenglish.com/opinion/2020/08/13/opinion-student-protest-leaders-lack-a-coherent-strategy/

Pongsudhirak, T. (2020, September 25). Reforms need broadening of the agenda. Bangkok Post. https://www.bangkokpost.com/opinion/opinion/1991123/reforms-need-broadening-of-the-agenda

Prizzia, R. (1985). Thailand in Transition: The Role of Oppositional Forces (ASIAN STUDIES AT HAWAII) (1st ed.). Univ of Hawaii Pr. https://doi.org/10.2307/2056072

Satrusayang, C. (2020, September 1). "If politics was good" trends on twitter in Thailand. Thai Enquirer. https://www.thaienquirer.com/17790/if-politics-was-good-trends-on-twitter-in-thailand/

Sattaburuth, A. (2020, October 18). House "must step in to end crisis." Bangkok Post. https://www.bangkokpost.com/thailand/politics/2003787/house-must-step-in-to-end-crisis 
\#SaveWanchalerm: Bangkok protest to demand answers on abducted exile. (2020, June 5).

Https://Sg.News.Yahoo.Com/. https://sg.news.yahoo.com/savewanchalerm-bangkok-protest-demand-answers041733653.html

Sawasdee, S. N. (2019). Electoral integrity and the repercussions of institutional manipulations: The 2019 general election in Thailand. Asian Journal of Comparative Politics, 5(1), 52-68. https://doi.org/10.1177/2057891119892321

Slight majority says "no-one" suitable to be PM: Poll. (2020, September 27). Bangkok Post. https://www.bangkokpost.com/thailand/politics/1992391/slight-majority-says-no-one-suitable-to-be-pm-poll

Somkiat warns crisis close to boiling point. (2020, October 26). Bangkok Post. https://www.bangkokpost.com/thailand/politics/2008119/somkiat-warns-crisis-close-to-boiling-point

Stowe, J. A. (1991). Siam Becomes Thailand: A Story of Intrigue. Univ of Hawaii Pr. https://doi.org/10.1086/ahr/98.1.221-a

Tejapira, K. (2016). The Irony of Democratization and the Decline of Royal Hegemony in Thailand. In Southeast Asian Studies, Vol. 5, No. 2, (2nd ed., Vol. 5, pp. 219-237). CSEAS Journal. https://doi.org/10.20495/seas.5.2_219

Thai PM says protesters' call for monarchy reform 'went too far.' (2020, August 12). Aljazeera. https://www.aljazeera.com/news/2020/08/12/thai-pm-says-protesters-call-for-monarchy-reform-went-too-far/

Thailand's protests and their digital dimension. (2020, October 18). DW. https://www.dw.com/en/thailands-protests-andtheir-digital-dimension/a-55315079

Tourism revenue could plummet over 75 per cent. (2020, August 8). The Nation | Thailand. https://www.nationthailand.com/business/30392672\#: :text=7\%20billion\%20next\%20year\%20due, around\%20 Bt3\%20trillion\%20last\%20year

Vipoosanapat, W. (2020, August 3). Can the online tactics of Thailand's political youth movement bring real change? Www.Fes-Connect.Org. https://www.fes-connect.org/trending/thailand-youth-protest/

Wangkiat, P., \& Mahtani, S. (2020, September 19). Tens of thousands rally against the government in Thailand, inspired by student leaders. The Washington Post. https:/www.washingtonpost.com/world/tens-of-thousands-rallyagainst-the-government-in-thailand-inspired-by-student-leaders/2020/09/19/7686fada-f3e8-11ea-80255d3489768ac8_story.html

Wilson, J., \& Satrusayang, C. (2020, May 15). The students in Thailand have come back as a political force; now they must focus and keep the momentum. Thai Enquirer. https://www.thaienquirer.com/12943/the-students-inthailand-have-come-back-as-a-political-force-now-they-must-focus-and-keep-the-momentum/

World Bank. (n.d.). World Bank national accounts data, and OECD National Accounts data files. Https://Data.Worldbank.Org/. Retrieved November 10, 2020, from https://data.worldbank.org/indicator/NY.GDP.MKTP.KD.ZG?locations=TH

Wright, J. J. (1991). The balancing act: A history of modern Thailand. Pacific Rim Press. https://doi.org/10.2307/2059134

Wyatt, D. K. (2003). Thailand: A Short History (2nd Revised ed.). Yale University Press. https://doi.org/10.1086/ahr/90.5.1259

ตั้งธรรมนิยม, K. (2020, August 12). เลียบวิภาวดี. Www.Naewna.Com. https://www.naewna.com/politic/columnist/44933

ทหาร ไล่เก็บป้ายผ้าต้านรัฐประหารกลางเมืองสารคาม. $\quad(2014, \quad$ May $\quad 24) . \quad$ Prachatai. https://prachatai.com/journal/2014/05/53460

ในหลวงตรัส “กล้ามาก เก่งมาก ขอบใจ" ชายชูพระบรมฉายาลักษณ์ ร.ศ์ กลางผู้ประท้วง (ชมคลิป). (2020, October 24). [Forum]. Mgronline.Com. https://mgronline.com/onlinesection/detail/9630000108677

ประยุทธ์ จันทร์โอชา. (2020, October 16). ไอ้เหี้ยโอ เด็กนักเรียนมัธยมเดินขบวนรับเสด็จ ด้วยประโยค 3 คำ (ไอ้ เหี้ย โอ) $\square \square \square$ [Video]. Youtube. https://www.youtube.com/watch?v=_OnBs5YE6a8

แฟลชม็อบนักเรียน-นักคึกษา ประกายไฟในกระทะ หรือ เพลิงลามทุ่ง. (2020, February 28). BBC News ไทย. https://www.bbc.com/thai/thailand-51640629

“เยาวชนปลดแอก” เปิดแถลงการณ์ข้อเรียกร้องฉบับเต็ม. (2020, July 19). Www.Bangkokbiznews.Com. https://www.bangkokbiznews.com/news/detail/890036

รอยัลลิสต์มาร์เก็ตเพลส-ตลาดหลวง. $\quad$ (n.d.). Www.Facebook.Com. $\quad$ Retrieved $\quad$ November $\quad 11, \quad 2020, \quad$ from https://www.facebook.com/groups/634791290746287/?ref=group_header

องค์กรเก็บขยะแผ่นดิน. (n.d.). Www.Facebook.Com. Retrieved November 11, 2020, from https://www.facebook.com/thaigoldmedal/ 